\title{
NUTRITIONAL AND ANTI-NUTRITIONAL PROPERTIES OF THE SEEDS OF SIX SELECTED NIGERIAN CUCURBIT GERMPLASM
}

\author{
$\underline{\text { Ibrahim Umar KARAYE }}^{1 *}$, Muhammad HAYATU², Yahya MUSTAPHA², \\ Lawan Abdu SANI ${ }^{2}$ \\ ${ }^{1}$ Department of Biological Sciences, Usmanu Danfodiyo University, Sokoto - Nigeria. \\ ${ }^{2}$ Department of Plant Biology, Bayero University, Kano - Nigeria. \\ * Corresponding author. E-mail: ikaraye09@yahoo.com
}

\begin{abstract}
Biochemical characterization of the seed extracts of the seeds of six selected Nigerian cucurbit germplasm was carried out using standard biochemical procedures. All treatments were replicated three times and the results presented as mean \pm S.E. On proximate analysis, percentage moisture ranged from $(3.83 \pm 0.10 \%)$ to $(5.17 \pm 0.65 \%)$ with the highest in Lagenaria breviflora $(5.17 \pm 0.65 \%)$ while the least value $(3.83 \pm 0.10 \%)$ was obtained in Cucurbita pepo. Crude protein composition ranged from (32.66-0.11) to (35.94 $\pm 2.89 \%)$ the highest (35.94 $\pm 2.89 \%)$ in Lagenaria breviflora while the least (32.66-0.11\%) was for Cucurbita maxima. Crude carbohydrate ranged from $(27.33 \pm 0.20)$ to $(36.66 \pm 0.2)$ with the highest $(35.66 \pm 0.20)$ in Citrullus lanatus while the least $(27.33 \pm 0.20)$ was for Cucurbita pepo. Crude lipid analysis showed the range of values $(31.33 \pm 0.27 \%)$ to $(24.50 \pm 0.29 \%)$ with the highest in Cucumeropsis mannii while Citrullus lanatus had $(24.50 \pm 0.29 \%)$. Crude fiber contents ranged from $(15.83 \pm 1.23 \%)$ to $(5.68 \pm 0.87 \%)$ with the highest $(15.83 \pm 1.23 \%)$ in Cucurbita maxima while Lagenaria breviflora had $(5.83 \pm 0.07 \%)$. Ash content revealed the range of values $(9.17 \pm 0.52)$ to $(5.86 \pm 0.29 \%)$ with the highest $(9.17 \pm 0.52 \%)$ in Cucurbita maxima while the least $(5.86 \pm 0.29 \%)$ was in Lagenaria breviflora. Analysis of available energy (kcal.) revealed the range of values $(555.97 \pm 2.45)$ to $(500.90 \pm 2.21 \mathrm{kcal})$ with the highest in Cucumeropsis mannii while Citrullus lanatus had $(500.90 \pm 2.21 \mathrm{kcal})$. With significant difference $(\mathrm{P} \leq 0.05)$ in the contents of crude carbohydrates, lipids, crude fiber and available energy in (kcal). Mineral analysis revealed nitrogen $(\mathrm{N})$ composition with a range of values $(3.11 \pm 0.38)$ to $(5.75 \pm 0.97 \mathrm{~g} / 100 \mathrm{~g})$ with the highest in Lagenaria breviflora while the least $(3.11 \pm 0.38) \mathrm{g} / 100 \mathrm{~g}$ was in Citrullus lanatus. Sodium (Na) analysis revealed the range of values $(11.83 \pm 0.79)$ to $(31.67 \pm 2.43) \mathrm{g} / 100 \mathrm{~g}$ with the highest in Cucurbita pepo $(31.67 \pm 2.43) \mathrm{g} / 100 \mathrm{~g}$ while Cucumeropsis mannii had the least $(11.83 \pm 0.79 \mathrm{~g} / 100 \mathrm{~g})$. Magnesium $(\mathrm{Mg})$ analysis similarly revealed range of values $(22.00 \pm 1.18)$ to $(34.60 \pm 2.17) \mathrm{g} / 100 \mathrm{~g}$ with the highest in Cucurbita maxima $(34.60 \pm 2.17) \mathrm{g} / 100 \mathrm{~g}$ while the least value $(22.00 \pm 1.18 \mathrm{~g} / 100 \mathrm{~g})$ was in Lagenaria siceraria. Similarly, calcium $(\mathrm{Ca})$ analysis revealed the presence of the valuable mineral with a range of values $(10.83 \pm 1.32)$ to $(36.67 \pm 2.76) \mathrm{g} / 100 \mathrm{~g})$ with highest $(36.67 \pm 2.67$ $\mathrm{g} / 100 \mathrm{~g})$ in Cucurbita maxima while the least $(10.83 \pm 1.32 \mathrm{~g} / 100 \mathrm{~g})$ was obtained in Cucurbita maxima. Contents of phosphorus $(\mathrm{P})$ revealed the range of values $(4.50 \pm 0.66)$ to $(5.71 \pm 0.98) \mathrm{g} / 100 \mathrm{~g}$ with the highest $(5.71 \pm 0.98 \mathrm{~g} / 100 \mathrm{~g})$ in Lagenaria siceraria while least $(4.50 \pm 0.66) \mathrm{g} / 100 \mathrm{~g}$ was obtained in Citrullus lanatus. More so, analysis of potassium $(\mathrm{K})$ revealed a range of values $(1,266.67 \pm 3.67)$ to $(2,266.70 \pm 3.69 \mathrm{~g} / 100 \mathrm{~g})$ with the highest $(2,266.70 \pm 3.69) \mathrm{g} / 100 \mathrm{~g}$ in the seeds of Cucurbita maxima while the least $(1,266.67 \pm 3.67$ $\mathrm{g} / 100 \mathrm{~g})$ was obtained in Citrullus lanatus. With significant difference $(\mathrm{P} \leq 0.05)$ among the species in the contents of sodium, magnesium, calcium and potassium. Based on phytochemicals analyzed, tannin content was highest in the seeds of Citrullus lanatus with $(29.66 \pm 2.26)$ while the least value $(11.62 \pm 0.84)$ was obtained in Cucurbita maxima. Volatile oil analysis ranged from (25.47 \pm 1.90$)$ in Lagenaria siceraria while the least $(11.68 \pm 0.69)$ was obtained in Cucurbita pepo. There is significant difference $(\mathrm{P} \leq 0.05)$ in the contents of phenol between Citrullus lanatus and the other species. Also, similar trend have been found to occur in the composition of saponin glycosides, as well as the volatile oil. Based on these results, it can be asserted that seeds of the members of Cucurbitaceae are high in proximate, minerals and phytochemicals that could be harnessed as food by man as well as used in animal feed formulation strategies in addition to various vital applications of the phytochemicals evaluated in the seeds.
\end{abstract}

Keywords: Antinutritional, Citrullus, Cucumeropsis, Cucurbita, feed - formulation, Lagenaria, nutritional. 


\section{Introduction}

Cucurbits are among the many plant species endowed with various potentialities that if properly harnessed, could help in achieving food security and generate job opportunities to our teeming populace as evident in Latin America and Asia. It is a known fact that nutritional contents of plant species could be affected by a number of environmental factors in addition to other parameters. Thus, is highly imperative to provide reports on the profile of each of the plant in its own geographical area for people to appreciate so, in addition to creating awareness to the populace on the importance of utilizing the locally available plant resource as evident in developed and some developing countries in the world. Cucurbits refer to those plant species placed in the large family of Angiosperm, known as Cucurbitaceae. Members of the gourd family that includes hundreds of species of vines with coiled climbing tendrils characterized by production of the most unusual fruits in the world. Cucurbitaceae family is among the abundant crop domesticated and grown at wild in most tropics (especially in Nigeria). Members of Cucurbitaceae are known to be very useful, serving as food, ornamental purposes, utensils, fuel as well as medicinal purposes [ABASCAL \& YARMELL, 2005]. In Nigeria, Cucurbitaceae is represented by 21 genera, and 41 species many of which are of considerable economic importance. Indigenous people of Nigeria traditionally utilize a wide range of these plant species as food and medicine. Archeological evidence has indicated that cucurbits were present in ancient and prehistoric cultures. Lagenaria for instance, was associated with man as early as 12 , $000 \mathrm{BC}$ in Peru. Archeological expeditions in the Oaxaca region of Mexico have reported Cucurbita pepo to be associated with man as early as $8500 \mathrm{BC}$ and cultivated by $4050 \mathrm{BC}$ [ESQUINAS-ALCAZAR \& GULICK, 1983].

Similarly, written Chinese records describing the use of cultivated cucurbits have been found as from as early as $685 \mathrm{BC}$. American Indians cultivated squash in pre-Columbian times. Cucurbits are among the economically most important vegetable crops worldwide and are grown in both temperate and tropical regions [PITRAT \& al. 1999; BISOGNIN, 2002].Despite their agronomic, cultural and culinary importance, there is scanty of information on these species from research and development and are often categorized as orphan crops [HAIM, 2007]. Members of Cucurbitaceae are known to be very useful, serving as food, ornamental purposes, utensils, fuel as well as medicinal purposes. In Nigeria, Cucurbitaceae is represented by 21 genera, many of which are of considerable economic importance. Indigenous people of Nigeria traditionally utilize a wide range of these plant species as food and medicine. Archeological evidence has indicated that cucurbits were present in ancient and prehistoric cultures. Lagenaria for instance, was associated with man as early as 12, 000 BC in Peru. Archeological expeditions in the Oaxaca region of Mexico have reported Cucurbita pepo to be associated with man as early as $8500 \mathrm{BC}$ and cultivated by $4050 \mathrm{BC}$ [ESQUINAS-ALCAZAR \& GULICK, 1983]. Similarly, written Chinese records describing the use of cultivated cucurbits have been found as from as early as 685 BC. American Indians cultivated squash in preColumbian times.

\section{Cucurbits in nutrition}

The necessity to feed the rapidly expanding human population remains the major task to accomplish. In order to have a healthy population that can promote development, the relationship between food, nutrition and health must be reinforced [OBI \& al. 2004]. This becomes imperative since large segments of the population especially in developing countries suffer from protein malnutrition and projections based on current trends indicate a widening gap between human population and protein supply [ABDELATIEF, 2011]. This explains why today, 
Ibrahim Umar KARAYE \& al.

food shortage remains a serious problem especially in Africa with about 36 million humans starving to death every year coupled with childhood malnutrition, which contribute to the global burden of disease [MURRAY \& LOPEZ, 1997].

There is a need to develop other sources of concentrated plant proteins [VOSE, 1980] which ideally should be crops that are widely grown in tropical countries [ABDELATIEF, 2011]. The consumption of whole-plant foods slows digestion and allows better absorption, and a more favourable balance of essential nutrients per calorie, resulting in better management of cell growth, maintenance, and mitosis as well as better regulation of appetite and blood sugar. Many plant proteins usually in the form of protein extracts or seed flours are being investigated and tested for new products such as low cost fabricated foods that are nutritious, attractive and acceptable to consumers. Seeds of cucurbits have been reported to have nutritive and calorific values, which make them necessary in diets [HAMZA \& al. 1995].

\section{Botany of plants studied}

The family Cucurbitaceae consists of members commonly known as gourds that include cucumbers, squashes, luffas and melons. Cucurbits are among the economically most important vegetable crops [LOUKOU \& al. 2007]. The family is distributed around the tropics, where those with edible fruits were among the earliest cultivated plants in both the old and new worlds. It is a large family with about 125 extant genera and 960 species [JEFFREY, 1978]. The family is represented by 21 genera and 41 species in Nigeria [HUTCHINSON, 1954]. Melon, pumpkin and gourd seeds are reported to be rich in protein and could be useful in fortification of food products [ABIODUN \& ADELEKE, 2010].

\section{Citrullus lanatus (Thunb.) Matsum. \& Nakai: the watermelon}

Watermelon, otherwise locally known as 'Kankana' in Hausa language is considered as a prominent member of the large family Cucurbitaceae. The plant is believed to have originated in southern Africa, particularly the Kalahari desert, where the plant is found growing wild with a high genetic diversity there, resulting in sweet, bland and bitter forms. There are a number of facts to prove that watermelon was indigenous to tropical Africa and increase in popularity of the species became widespread early in history and today; it is cultivated throughout the world The crop can be described as a deep-rooted with ability to survive in relatively dry conditions of the northern part of the country, the relatively dry conditions of the northern part of the Nigeria supports higher production yield of crop. In addition, better yield is obtained with irrigation in the region [ILELABOYE \& PIKUDA, 2009]. The pulp of the fruit is highly cherished and eaten ripe. In some parts of the world as Nigeria and Middle East countries, the seeds are used for extracting cooking oil while in majority of the countries, its utility is restricted for additive purpose. The seeds are used as condiment, garnisher and thickener in soups; fat binder, flavourants and as snack in most parts of the world [EL-ADAWY \& TAHA, 2001].

Watermelon is characterized by sweet and juicy fruit containing high content of lycopene [LIU \& al. 2013]. The production of watermelon accounts for approximately $9.5 \%$ of total vegetable production in the world [FAO, 1973]. Watermelon fruit contains a variety of nutrients including fiber, vitamins, antioxidants and minerals, which are essential for human health. The commercial quality of watermelon fruits is determined by many factors such as fruit size and shape, rind color and thickness, flesh color and texture, sugar content, aroma, flavor and nutrient composition. The sweet, colored and juicy fruit makes it the model system for the study of sugar and carotenoids metabolism of non-climacteric fleshy fruit [GUO \& al. 2011]. 


\section{Cucurbita maxima Duchesne: the winter squash}

C. maxima its common name is winter squash or 'kabewa' in Hausa language. The species is believed to have originated from South America some 4,000 years ago. This cucurbit is a perennial creeping herb, that can grow up to $10 \mathrm{~m}$ long, unisexual with the calyx joined to the corolla while the male ones having the stamens connected into column. Hirsute stems, lobed. Its leaves are 20-30 centimeters wide. It generally grows at low altitudes in hot climates with heavy rainfall, but some varieties have been found above 2,200 meters. Pumpkin seeds are flat, dark green and some are enclosed in a yellow-white husk although some varieties of pumpkins produce seeds without shells. The seeds have a malleable, chewy texture and a subtly sweet, nutty flavor that are delicious and nutritious. The fruits are variable in size, color, shape and weight. The seeds of pumpkins are becoming popular in Africa for their medicinal properties and they are eaten as antihelmintic. They are characterized by moderately hard rind, with a thick, edible flesh below, and a central seed cavity. There are numerous seeds in the fruits [MUHAMMAD, 2004]. The seeds are plump, covered with a testa that serves a protectant around the seeds. The plants grow in vines that spread low across the ground with large leaves and yelloworange flowers. Pumpkin seeds are rich with both essential and non-essential amino acids.

\section{Cucurbita pepo L.: the pumpkins}

Cucurbita pepo L. is one of the oldest known cultivated species. The plant is native of Northern Mexico and southwestern and eastern USA. C. pepo is an annual creeping or climbing plant with 5-angled stems up to $15 \mathrm{~m}$ long. The shallow root system is branched, growing from a well-developed taproot. The stems are rugged and bristle, branching 6-24 cm long, usually rooting at the nodes. The plant bears tendrils at 90 degrees to the leaf insertion, which are coiled and 1-6 branched. On bushy plants, tendrils may be poorly developed. The leaves are simple, alternate, broadly ovate to deltoid, basally cordate, apically acute, palmately lobed with 5-7 lobes, marginally toothed, scabrous, palmately veined, 20-30 cm long, and 10-35 cm broad leaves with $5-25 \mathrm{~cm}$ petioles that are ovate-cordate to sub orbicular-cordate, with or without white spots on the surface and have three to five rounded or obtuse, apiculate lobules, the central one bigger than lateral ones.

Pumpkin is monoecious and bears solitary actinomorphic flowers $(-10 \mathrm{~cm}$ across $)$ that produce nectar. Male flowers are long and pedicellate and have a campanulate calyx that is 5 to $10 \mathrm{~mm}$ long and almost as wide 5-15 mm, 1-2 mm linear sepals and a tabular campanulate corolla that is rather broader towards the base, 6 to $12 \mathrm{~cm}$ long and yellow to pale orange. Flower has three stamens. Female flowers have thick peduncles, $3-5 \mathrm{~cm}$ long, an ovoid to elliptical, multilocular ovary, sepals that are occasionally foliaceous and a corolla is somewhat larger than that of the male flowers. They have a thickened style and three lobate stigmas. Fruits are variable in shape, color and size. It can be oval, cylindrical, flattened, globular, scalloped, fusiform, and or tapering curved or straight neck on one or both ends. Fruits are variable in size, color, shape and weight [MUHAMMAD, 2004]. They have a moderately hard rind, with a thick, edible flesh below, and a central seed cavity. There are numerous seeds in the fruit. Most seeds are plump and tan or soft white. They are all covered with a testa that serves as protectant around the seeds [ROBINSON \& DECKER-WALTERS, 1997]. A pumpkin seed orange flesh is eaten for human consumption such as soup, purees, jams, and pies throughout the world [MUHAMMAD, 2004]. It has been domesticated in the New World for thousands of years. Some authors maintain that Cucurbita pepo is derived from Cucurbita texana, while others suggest that $C$. texana is merely feral Cucurbita pepo. They have a wide variety of uses, especially as a food source and for medical conditions. Cucurbita pepo seems more closely related to Cucurbita fraterna, though disagreements exist about the exact nature of that connection. It is considered a delicacy in 
Ibrahim Umar KARAYE \& al.

traditional local cuisines such as for pumpkin soup, potato salad. Pumpkin seed oil contains fatty acids, such as oleic acid and alpha-linolenic acid.

\section{Lagenaria breviflora (Benth.) Roberty: the wild colocynth}

Lagenaria breviflora (Benth.) Roberty is another member of the family Cucurbitaceae. Common names wild colocynth (English) local names in Hausa include gojin jima; gunar jiímaà. Lagenaria breviflora is a perennial climber ascending to the forest canopy, occurring from Senegal to West Cameroons, and generally widespread in tropical Africa. The leaves very scabrid and sandpapery. The stem when broken has an unpleasant smell, and a decoction from it is said to be used in Nigeria for headache. The root is used in Tanganyika as a purgative and in Nigeria as a vermifuge. The fruits are dark green with creamy blotches, and are ovoid to 9 $\mathrm{cm}$ long. They are commonly used in Nigeria for depilating hides. The seeds are grey and $5 \mathrm{~mm}$ long by $3 \mathrm{~mm}$ wide. They are edible but similarly bitter, nutty-flavored, and rich in fat and protein. They are eaten whole or used as an oilseed. The fruits are cut up, put in water with lye of wood-ashes and in this hides are left to soak for one or two days. Alternatively the hides are stretched and the inner surface scraped clean, and then the fruit pulp is rubbed in followed by a free application of dry wood-ash. Depilating is done after the folded hide has been steeped for a further day in the lye of wood-ash. The fruit is perhaps also used in bating-bath to prepare skin to receive the tanning material [ADEDAPO \& al. 2013].

\section{Lagenaria siceraria (Molina) Standl.: the bottle gourd}

The origin of bottle gourd is acknowledged to be Africa, although archeological evidence has placed it in Peru around $12000 \mathrm{BC}$; in Thailand about $8000 \mathrm{BC}$, and in Zambia around 2000 BC [ESQUINAS-ALCAZAR \& GULICK, 1983]. It travelled widely, perhaps due to the hard, dry skin of the mature fruits is impervious to water; they are capable of floating on salt water for the better of a year without any loss in seed viability. Tolerant a wide range of rainfall, it may be grown either on the ground or trellised [NG, 1993]. Calabash possesses simple leaves which are $400 \mathrm{~mm}$ long and $400 \mathrm{~mm}$ broad, oval shape and whitish seeds embedded in a spongy pulp, 7-20 mm long. They are widely grown in Northern part of Nigeria for excavation of domestic utensil and food containers. The fruits of these species contain vast number of seeds that have no commercial application in the locality they are produced [SOKOTO \& al. 2013]. Phytogenetically, bottle gourd is close to many economically important cucurbit species including cucumber and melon that belong to the genus Cucumis as referred to as vegetable gourd of the family, Cucurbitaceae [WARRIER \& al. 1995]. Bottle gourd is among the earliest cultivated plants used for medicinal and nutritional values [DAVIES \&STEWART, 1990; DUKE, 1992; NEWEL \& al. 1996; PIZZORNO \& MURRAY, 1985; WERBACH, 1991].

Young fruits are used as cooked vegetables; the flesh is white, firm and has an excellent texture and mild taste. Young shoots and leaves can be cooked while the seeds can be used in soup preparations. They can be used as multi-purpose containers (bowls, boxes, water jugs, cups, and planters); utensils, ladles and pipes, musical instruments, floats for fishnets and rafts, or for ornamental purposes such as masks or native artifacts [NG, 1993].

\section{Cucumeropsis mannii Naudin: the Egusi}

Cucumeropsis mannii is a member of the melon native to tropical Africa west of the East African Rift where it is grown for food and as a source of edible oil. Cucumeropsis mannii is a member of the Cucurbitaceae family. Its common names include egusi in Yoruba and agushi in Hausa. In English it is known as Mann's Cucumeropsis and white-seed melon. It produces climbing vines up to 4 meters long which are covered in stiff hairs. The heart-shaped or roughly palmate leaves are up to 12 centimeters long and 14 wide. It bears small yellow male and female flowers with petals under a centimeter in length. The fruit is egg-shaped or an elongated ovate 
shape, up to about 19 centimeters long and 8 wide, and cream in color with green streaks. The fruit and white seeds are edible. The plant is grown more often for the seed oil than for the fruit. Vernacular names for this crop include egusi-itoo and white seed melon [OBUTE \& al. 2007].

The crop is often referred to as "the real egusi" given its long history in West Africa, dating back 4,000 years [KORTSE \& OLADIRAN, 2013]. This crop is primarily harvested for its large white seeds called egusi-itoo. The seeds are commonly processed into soups and oil products, and are also eaten individually as a snack. Benefits of Cucumeropsis mannii crops are many. The crop thrives in harsh climates and high yields are attainable in barren landscapes. Pests and disease are rarely a problem for farmers of this crop. Further benefits include increased soil quality through ground cover and suppression of weeds. This crop also holds significant nutritional value. Oil makes up $44 \%$ of the seed, where $30 \%$ is protein rich in essential amino acids. The seed is an excellent vegetable protein, and is ideal for battling nutritional debilitations. High in essential vitamins and minerals, egusi-itoo compliments the starch and grain diet of most Africans. Despite the crops obvious advantages, Cucumeropsis mannii remains an underutilized tool for nutritional intervention in Africa.

\section{Material and methods}

\section{Samples collection and preparation}

Fresh fruits of Citrullus lanatus, Cucurbita pepo and Cucurbita maxima were purchased at Kasuwan Daji market within the Sokoto municipal while freshly harvested seeds of Cucumeropsis mannii were purchased from Kasuwan Dankure market in Sokoto. Freshly harvested seeds of Lagenaria siceraria were purchased at Gummi market, Zamfara state while ripe and fully grown fruits of Lagenaria breviflora were obtained from roadsides in the outskirts of Sokoto town where the species was found growing as wild. All the six samples were taken to the Department of Biological Sciences Herbarium, Usmanu Danfodiyo University, Sokoto for authentication by a taxonomist where voucher specimens were deposited. Seeds were removed from the fruits by cutting the individual fruit longitudinally and scrapping out the seeds using cleaned knife. The seeds were removed from bad ones. The seeds were dried to a constant weight in an oven at $70^{\circ} \mathrm{C}$, milled using mechanical blender, placed in six labeled air-tight containers and stored in desiccators prior to analysis.

\section{Proximate composition analysis}

Proximate composition (crude proteins, crude lipids, fibre, moisture and ash) of the seeds of the sampled cucurbits were determined using the methods of Association of Official Analytical Chemists (1990) while carbohydrate was determined by difference. The calorific values in kilo joule $(\mathrm{k})$ were calculated by multiplying the crude fat, protein and carbohydrate by Atwater factors of (k) 37, 17, and 17 respectively.

\section{Mineral composition analysis}

The minerals were analyzed by first dry ashing the samples at $550{ }^{\circ} \mathrm{C}$ in the muffle furnace. The filtered solutions were used to determine $\mathrm{Na}, \mathrm{K}, \mathrm{Ca}, \mathrm{Mg}, \mathrm{P}$ and $\mathrm{N}$ by means of atomic absorption spectrophotometer [AAS] [Buck Scientific Model-200A/210, Norwalk, Connecticut [06855] and phosphorus was determined calorimetrically by Spectronic 20 [Gallenkamp, UK] using the phosphovanado molybdate method [AOAC, 2008].

\section{Quantitative phytochemical analysis}

Qualitative Phytochemicals of the samples were determined following the methods of TREASE \& EVANS (1978) and HARBONE (1998). 


\section{Data analysis}

Treatments were replicated three times and the data obtained has been presented as means \pm S.E. of the means. Results obtained were subjected to one way Analysis of Variance [ANOVA]. Same superscripts means that there was no significant difference $[\mathrm{P} \leq 0.05]$ and where the superscripts differ, it means that there was a significant difference $[\mathrm{P} \leq 0.05]$.

\section{Results and discussion}

\section{Proximate analysis}

Table 1 presents results of proximate analysis of the seeds of Nigerian cucurbits germplasm. Moisture contents ranges from $3.83 \pm 0.10 \%-5.1 \pm 0.65 \%$ with the highest content found in Lagenaria breviflora while the least value of $3.83 \pm 0.10 \%$ was obtained for Cucurbita pepo, Citrullus lanatus had $4.83 \pm 0.23 \%$ while Cucurbita maxima, Cucumeropsis mannii $4.67 \pm 0.19 \%$. This moisture content was in close agreement with the report of ACHU \& al. (2005) who reported moisture content of $6.49 \pm 0.62 \%$ on seeds of Cucumeropsis mannii while Cucurbita maxima had $6.94 \pm 1.92 \%$, Lagenaria siceraria with $6.09 \pm 0.20 \%$ and Cucurbita moschata with $8.21 \pm 1.47 \%$. Similarly, result compares with those as reported on protein composition of the seeds of some cucurbits by KARAYE \& al. (2013) who reported a range of 29.49. $\pm 0.87-33.48 \pm 0.87 \%$. In another study by ACHU \& al. (2005) (2005), range of crude protein content of Cucurbita maxima was $34.93 \pm 0.42 \%$ a range which is in close range with the obtained value in this study. In another study by JACOB \& al. (2015), moisture content and crude protein were $7.10 \%$ and $30.65 \%$ respectively as reported. In same study, crude lipid was $49.05 \%$ higher than obtained in this study. Lower values of crude fibre and ash contents were $6.00 \%$ and $4.52 \%$ respectively than obtained in the current study. The result is as well in close agreement with that reported on Cucumis sativus with $28.68 \pm 2.38 \%$ while Cucumeropsis mannii had $40.49 \pm 2.75 \%$ a bit higher than obtained in the current study. In another study by JACOB \& al. (2015), a closely related agreement on moisture and crude protein contents of $7.10 \%$ and $30.65 \%$ was reported on Citrullus lanatus seed extract. Crude lipid of the range of $24.50 \pm 0.29-31.33 \pm 0.34 \%$ obtained in this study was a bit lower than $38.00 \%$ as reported by ELINGE \& al. (2012) on Cucurbita pepo; and $49.05 \%$ on Citrullus lanatus seed extract as reported by JACOB \& al. (2015) on. The result obtained in this study is also lower than $44.85 \pm 4.03 \%$ and $49.05 \pm 2.48 \%$ as reported by ACHU \& al. (2005) on the seed extracts of Cucumeropsis mannii and C. maxima. Crude carbohydrate content obtained in the current study ranges from $24.06 \pm 0.08-36.34 \pm 0.29 \%$ which tallies with the reported $27.88 \pm 0.42-33.60 \pm 0.42 \%$ by KARAYE \& al. (2013) in another study on cucurbits seeds. Ash content reported by ACHU $\&$ al. (2005) C. mannii with $3.74 \pm 0.35 \%$ while that of Cucurbita moschata had $4.75 \pm 0.47 \%$. Different values were reported by KARAYE \& al. (2020) on Desert date (Balanites aegyptiaca) seed and fruit pulp extracts. These differences could be attributed to the species variability. This suggests the cucurbits seeds as rich sources of nutrients that could boost nutrients availability in the diets and their role in food and feed formulation strategies. Available energy (kilo calorie) obtained in this study was in agreements with that as reported by ELINGE \& al. (2012) 564.00 $\mathrm{kcal} / 100 \mathrm{~g}$ on Cucurbita pepo. Closely similar result was reported by GBOGOURI \& al. (2011) $526.53 \mathrm{kcal}$ in Cucumis melo and $572.00 \mathrm{kcal}$ on Citrullus lanatus seeds respectively. Also, in agreement with the report of JACOB \& al. (2015). This suggests the cucurbits seeds as veritable source of energy. 
NUTRITIONAL AND ANTI-NUTRITIONAL PROPERTIES OF THE SEEDS OF SIX SELECTED ...

Table 1. Proximate analysis of the seeds six Nigerian Cucurbits Germplasm (Presented as \% DW)

\begin{tabular}{|c|c|c|c|c|c|c|c|}
\hline Species & Moisture & Protein & $\begin{array}{c}\text { Carbo- } \\
\text { hydrates }\end{array}$ & Lipid & Fibre & Ash & $\begin{array}{c}\text { Energy } \\
\text { (K/Cal.) }\end{array}$ \\
\hline $\begin{array}{l}\text { Citrullus } \\
\text { lanatus }\end{array}$ & $a^{a}$ & $3^{\mathrm{a}}$ & $24.06 \pm 0.08^{\mathrm{a}}$ & 24.50 & 12.6 & $3^{\mathrm{a}}$ & $500.90 \pm 2.32^{\mathrm{a}}$ \\
\hline $\begin{array}{l}\text { Cucurbita } \\
\text { maxima }\end{array}$ & $57 \pm 0.19^{a}$ & $1^{\mathrm{a}}$ & $30.66 \pm 0.21^{\mathrm{b}}$ & $28.27 \pm$ & $3^{\mathrm{a}}$ & $0017+$ & $507.71 \pm 2.06^{b}$ \\
\hline Cucurbita pepo & $3.83 \pm$ & $\mathrm{z}^{\mathrm{a}}$ & 31.16 & $0^{\mathrm{b}}$ & 14. & & $506.64 \pm 2.24^{\mathrm{b}}$ \\
\hline $\begin{array}{l}\text { Cucumeropsis } \\
\text { mannii }\end{array}$ & $4.17 \pm 0.26^{\mathrm{a}}$ & $33.10 \pm 0.16^{\mathrm{a}}$ & $35.40 \pm 0.51^{\mathrm{c}}$ & 31.33 & 13.87 & $7.67 \pm$ & $555.97 \pm 2.21^{\mathrm{c}}$ \\
\hline $\begin{array}{l}\text { Lagenaria } \\
\text { breviflora }\end{array}$ & $17 \pm 0.65^{\mathrm{a}}$ & $35.94 \pm 0.26^{\mathrm{a}}$ & $36.34 \pm 0.29^{d}$ & $25.67 \pm 0.18^{b}$ & $5.83 \pm 0.07^{\mathrm{b}}$ & $5.86 \pm 0.29^{\mathrm{a}}$ & $520.15 \pm 2.10^{\mathrm{d}}$ \\
\hline $\begin{array}{l}\text { Lagenaria } \\
\text { siceraria }\end{array}$ & $33 \pm 0.27^{\mathrm{a}}$ & $33.10 \pm 0.08^{a}$ & $34.10 \pm 0.26^{\mathrm{d}}$ & $27.17 \pm 0.20^{\mathrm{b}}$ & $6.33 \pm 0.09^{b}$ & $6.17 \pm 0.36^{\mathrm{a}}$ & $513.33 \pm 2.12^{\mathrm{e}}$ \\
\hline
\end{tabular}

Results presented as mean \pm S.E. of the means. All treatment were replicated three times. Different superscripts indicate significant difference at $\mathrm{p} \leq 0.05$.

\section{Mineral analysis}

Mineral analysis of the seeds of six selected cucurbits germplasm has been presented in Table 2. Results of the analysis of the seeds revealed a high proportion of the vital biochemicals necessary for healthy growth and development. The range of values obtained for $\mathrm{Ca}$ in this study was $10.83 \pm 1.32-34.67 \pm 2.76$. This is in close agreement with results reported by JACOB \& al. (2015) $\mathrm{Mg}$ as $20.46 \mathrm{mg} / 100 \mathrm{~g}$. Also, in close agreement with $22.33 \mathrm{mg} / 100 \mathrm{~g}$; and $23.67 \mathrm{mg} / 100$ $\mathrm{g}$ as reported by KARAYE \& al. (2020) on Balanites aegyptiaca seed extract. Magnesium is an activator of many enzyme systems and helps in the maintenance of electrical potential in nerve [ONIBON \& al. 2007]. Similarly, calcium content obtained in this study $(22.00 \pm 1.80)$ to (34.60 \pm 2.23$)$ was in disagreement with $9.78 \mathrm{mg} / 100 \mathrm{~g}$ as reported by ELINGE \& al. (2012) on seeds of pumpkin. $\mathrm{Ca}$ and $\mathrm{Mg}$ as reported on $C$. mannii were higher than obtained in this study. Calcium has been reported to help in the regulation of muscular constrictions, transmits nerve impulse and has been implicated for bone formation. Calcium intake especially from regular use of calcium supplements may be associated with increased risk of kidney stone. In another study by GBOGOURI \& al. (2011), values reported for K and Na were 806.10 \pm 21.21 and 11.00 \pm 2.31 for Cucumeropsis mannii which were in close agreement to those obtained in this study. Sodium plays an important role in osmotic regulation of the body fluids and transmission of nerve impulses. $\mathrm{Na} / \mathrm{K}$ ratio in the body is important because it helps in controlling high blood pressure. $\mathrm{Na} / \mathrm{K}$ ratio of less than one is recommended [YUSUF \& al. 2007]. Potassium content of the seeds obtained was higher than those reported for the fruit pulp and the seeds $383.33 \pm 12.47$ and $256.33 \pm 10.47$ for Balanites aegyptiaca by KARAYE \& al. (2020). These differences could be attributed to species variability. It was reported that plant foods have high amount of potassium [HASSAN \& al. 2006]. High amount of potassium in the body was reported to increase iron utilization [ADEYEYE, 2002].

Table 2. Results of mineral analysis of the seeds of six Nigerian Cucurbit Germplasm.

Results presented as $\mathrm{g} / 100 \mathrm{~g}$

\begin{tabular}{lcccccc}
\hline \multicolumn{1}{c}{ Species } & $\mathbf{N}$ & $\mathbf{N a}$ & $\mathbf{M g}$ & $\mathbf{C a}$ & $\mathbf{P}$ & $\mathbf{K}$ \\
\hline $\begin{array}{l}\text { Citrullus lanatus } \\
\text { Cucurbita }\end{array}$ & $3.11 \pm 0.38^{\mathrm{a}}$ & $15.83 \pm 1.65^{\mathrm{a}}$ & $22.33 \pm 2.03^{\mathrm{a}}$ & $10.83 \pm 1.32^{\mathrm{a}}$ & $4.50 \pm 0.86^{\mathrm{a}}$ & $1266.67 \pm 3.67^{\mathrm{a}}$ \\
\hline \begin{tabular}{l} 
maxima \\
\hline Cucurbita pepo
\end{tabular} & $5.24 \pm 0.78^{\mathrm{a}}$ & $20.83 \pm 2.12^{\mathrm{b}}$ & $34.60 \pm 3.17^{\mathrm{b}}$ & $36.67 \pm 2.76^{\mathrm{b}}$ & $4.54 \pm 0.98^{\mathrm{a}}$ & $2266.70 \pm 5.69^{\mathrm{b}}$ \\
\hline $\begin{array}{l}\text { Cucumeropsis } \\
\text { mannii }\end{array}$ & $3.12 \pm 0.50^{\mathrm{a}}$ & $11.83 \pm 0.79^{\mathrm{d}}$ & $21.77 \pm 2.24^{\mathrm{a}}$ & $11.77 \pm 0.98^{\mathrm{c}}$ & $5.11 \pm 0.76^{\mathrm{a}}$ & $1550.00 \pm 4.54^{\mathrm{b}}$
\end{tabular}


Ibrahim Umar KARAYE \& al.

\begin{tabular}{lllllll}
\hline $\begin{array}{l}\text { Lagenaria } \\
\text { breviflora }\end{array}$ & $5.75 \pm 0.97^{\mathrm{a}}$ & $24.17 \pm 2.32^{\mathrm{d}}$ & $34.60 \pm 2.23^{\mathrm{b}}$ & $36.67 \pm 2.74^{\mathrm{b}}$ & $4.54 \pm 0.44^{\mathrm{a}}$ & $2266.67 \pm 5.66^{\mathrm{c}}$ \\
\hline $\begin{array}{l}\text { Lagenaria } \\
\text { siceraria }\end{array}$ & $5.30 \pm 0.69^{\mathrm{a}}$ & $21.67 \pm 2.21^{\mathrm{b}}$ & $22.00 \pm 1.18^{\mathrm{c}}$ & $31.33 \pm 1.98^{\mathrm{b}}$ & $5.71 \pm 0.74^{\mathrm{a}}$ & $1783.33 \pm 4.92^{\mathrm{b}}$ \\
\hline Rerari & & & & &
\end{tabular}

Results have been presented as means \pm Standard Error of the means. All treatments were replicated three times. Different superscripts indicate significant difference at $\mathrm{p} \leq 0.05$.

\section{Results of Quantitative Phytochemicals}

Quantitative analysis of the seeds of six selected cucurbits germplasm has been presented in Table 3. Phytochemicals are plant compounds that have interest as a source of safer or more valuable substitutes than synthetically created antimicrobial agents. Phytochemical progress has been aided extremely by the development of rapid and accurate methods of screening plants for particular chemicals [ATIF \& al. 2012]. From the results, flavonoid contents revealed the highest in Lagenaria siceraria $(23.33 \pm 1.66)$ while the least was identified (12.67 \pm 0.84$)$ in Citrullus lanatus. Terpenoid was highest in Cucumeropsis mannii $(23.67 \pm 1.92)$ while the least $(14.57 \pm 0.99)$ was obtained in Cucurbita pepo. Glycoside was evaluated with highest in Lagenaria breviflora (27.23 \pm 2.06 ) while the least was found in Lagenaria siceraria (14.57 \pm 1.03$)$. Alkaloid was identified to be highest in Cucurbita pepo while the least $(24.43 \pm 1.18)$ was identified in Cucurbita maxima. Saponin glycoside was evaluated and the highest was identified in Citrullus lanatus with $(28.81 \pm 2.06)$ while the least $(12.67 \pm 0.76)$ was identified in Cucumeropsis mannii. The values were higher than (3.20 \pm 0.40$)$ and $(2.60 \pm 0.35)$ as reported on seeds and dry pulp of Balanites aegyptiaca by KARAYE \& al. (2020). Also, lower value $(3.13 \mathrm{mg} / 100 \mathrm{~g})$ was reported on dehulled seeds of Luffa aegyptiaca. These differences could be attributed to species variability. Tannin is an astringent, bitter plant polyphenolic compound that either binds or precipitates proteins and various other organic compounds including amino acids and alkaloids [REDDEN \& al. 2005]. The term is applied to any large polyphenolic compound containing sufficient hydroxyls and other suitable groups to form strong complexes with proteins and other macromolecules. Tannins have molecular weights ranging from 500 to over 3000 [MUZQUIN \& al. 2000]. Saponin are secondary compounds that are generally known as non-volatile, surface active compounds which are widely distributed in nature, occurring primarily in the plant kingdom. Saponin molecules form soap-like foams when shaken with water. They are structurally diverse molecules that are chemically referred to as triterpene and steroid glycosides. They consist of non-polar aglycones coupled with one or more monosaccharide moieties. This combination of polar and non-polar structural elements in their molecules explains their soap-like behavior in aqueous solutions [GEMADEH \& RATTA, 2014]. Saponin have found wide applications in beverages and confectionery as well as in cosmetics and pharmaceutical products. Due to the presence of a lipid-soluble aglycones and water soluble sugar chain (s) in their structure (amphiphilic nature), saponins are surface active compounds with detergent, wetting, emulsifying and foaming properties [SHANTHAKUMARI \& al. 2008]. Saponins are attracting considerable interest as a result of their beneficial effects in humans. Recent evidence suggests that saponins possess hypocholesterolemic, immunostimulatory and anticarcinogenic properties. In addition, they reduce the risk of heart diseases in humans consuming a diet rich in legumes containing saponins. Saponin-rich foods are important in human diets to control plasma cholesterol, preventing peptic ulcer, osteoporosis and reduce the risk of heart disease. Saponins are used as adjuvants in viral and bacterial vaccine (e.g. Quillaja saponins) applications. In epidemiological studies, saponins have been shown to have an inverse relationship with the incidence of renal stones [LOEWUS, 2002]. Alkaloids are one of the largest groups of chemical compounds 


\section{NUTRITIONAL AND ANTI-NUTRITIONAL PROPERTIES OF THE SEEDS OF SIX SELECTED ...}

synthesized by plant acids such as oxalic, malic, tartaric or citric acid. Alkaloids are small organic molecules, common to about 15 to 20 percent of all vascular plants, usually comprising several carbon rings with side chains, one or more of the carbon atoms being replaced by a nitrogen. They are synthesized by plants from amino acids. Decarboxylation of amino acids produces amine oxides to form aldehydes. The characteristic heterocyclic ring in alkaloids is formed from Mannich-type condensation from aldehyde and amine groups [FELIX \& MELLO, 2000].

Table 3. Results of Quantitative Phytochemicals of the seeds of six cucurbits germplasm

(Results presented as \% DW)

\begin{tabular}{lcccccc}
\hline Phytochemicals & $\begin{array}{c}\text { Citrullus } \\
\text { lanatus }\end{array}$ & $\begin{array}{c}\text { Cucurbita } \\
\text { maxima }\end{array}$ & $\begin{array}{c}\text { Cucurbita } \\
\text { pepo }\end{array}$ & $\begin{array}{c}\text { Cucumeropsis } \\
\text { mannii }\end{array}$ & $\begin{array}{c}\text { Lagenaria } \\
\text { breviflora }\end{array}$ & $\begin{array}{c}\text { Lagenaria } \\
\text { siceraria }\end{array}$ \\
\hline Flavonoid & $12.67 \pm 0.84^{\mathrm{a}}$ & $14.63 \pm 0.96^{\mathrm{a}}$ & $16.12 \pm 1.00^{\mathrm{a}}$ & $14.64 \pm 0.97^{\mathrm{a}}$ & $12.77 \pm 0.89^{\mathrm{a}}$ & $23.33 \pm 1.66^{\mathrm{b}}$ \\
Terpenoid & $17.16 \pm 1.11^{\mathrm{a}}$ & $16.23 \pm 1.02^{\mathrm{a}}$ & $14.57 \pm 0.99^{\mathrm{a}}$ & $23.67 \pm 1.92^{\mathrm{b}}$ & $16.77 \pm 1.00^{\mathrm{a}}$ & $21.17 \pm 1.37^{\mathrm{b}}$ \\
Glycoside & $23.66 \pm 1.16^{\mathrm{a}}$ & $24.53 \pm 1.28^{\mathrm{a}}$ & $15.62 \pm 1.10^{\mathrm{b}}$ & $23.67 \pm 1.17^{\mathrm{a}}$ & $27.23 \pm 2.06^{\mathrm{c}}$ & $14.57 \pm 1.03^{\mathrm{a}}$ \\
Alkaloid & $26.23 \pm 1.91^{\mathrm{a}}$ & $24.45 \pm 1.19^{\mathrm{a}}$ & $29.79 \pm 2.21^{\mathrm{a}}$ & $24.77 \pm 1.54^{\mathrm{a}}$ & $28.66 \pm 2.07^{\mathrm{a}}$ & $27.76 \pm 2.00^{\mathrm{a}}$ \\
Saponin & $28.81 \pm 2.06^{\mathrm{a}}$ & $19.23 \pm 1.05^{\mathrm{b}}$ & $14.38 \pm 0.97^{\mathrm{c}}$ & $12.67 \pm 0.76^{\mathrm{c}}$ & $13.68 \pm 0.73^{\mathrm{c}}$ & $15.23 \pm 0.99^{\mathrm{c}}$ \\
Tannin & $29.66 \pm 2.26^{\mathrm{a}}$ & $11.62 \pm 0.84^{\mathrm{b}}$ & $24.66 \pm 1.31^{\mathrm{a}}$ & $25.61 \pm 1.86^{\mathrm{a}}$ & $24.23 \pm 1.49^{\mathrm{a}}$ & $25.87 \pm 1.87^{\mathrm{a}}$ \\
Phenol & $28.61 \pm 2.21^{\mathrm{a}}$ & $12.53 \pm 0.86^{\mathrm{b}}$ & $24.43 \pm 1.41^{\mathrm{c}}$ & $11.68 \pm 0.81^{\mathrm{b}}$ & $24.66 \pm 1.51^{\mathrm{c}}$ & $29.62 \pm 2.23^{\mathrm{a}}$ \\
Cardiac & $26.23 \pm 1.87^{\mathrm{a}}$ & $24.47 \pm 1.28^{\mathrm{a}}$ & $25.62 \pm 1.89^{\mathrm{a}}$ & $24.27 \pm 1.26^{\mathrm{a}}$ & $21.67 \pm 1.10^{\mathrm{a}}$ & $22.23 \pm 1.21^{\mathrm{a}}$ \\
glycoside & $11.67 \pm 0.89^{\mathrm{a}}$ & $12.82 \pm 0.92^{\mathrm{a}}$ & $29.62 \pm 2.45^{\mathrm{b}}$ & $11.86 \pm 0.84^{\mathrm{a}}$ & $24.47 \pm 1.48^{\mathrm{b}}$ & $25.67 \pm 1.93^{\mathrm{b}}$ \\
Cyanide & $12.23 \pm 0.91^{\mathrm{a}}$ & $11.66 \pm 0.82^{\mathrm{a}}$ & $24.23 \pm 1.24^{\mathrm{b}}$ & $21.87 \pm 1.16^{\mathrm{b}}$ & $11.66 \pm 0.86^{\mathrm{a}}$ & $24.47 \pm 1.90^{\mathrm{b}}$ \\
Resin & $24.12 \pm 1.48^{\mathrm{a}}$ & $25.31 \pm 1.69^{\mathrm{a}}$ & $11.68 \pm 0.69^{\mathrm{b}}$ & $24.67 \pm 1.47^{\mathrm{a}}$ & $25.23 \pm 1.57^{\mathrm{b}}$ & $25.47 \pm 1.90^{\mathrm{b}}$ \\
\hline Volatile oil & &
\end{tabular}

Results presented as means \pm Standard error of three replications. Same superscripts indicated no significant difference in means at $(\mathrm{P} \leq 0.05)$, while where superscripts differ, it means there is significant difference $(\mathrm{P} \leq 0.05)$.

\section{Conclusions}

Based on the results of the current study, it can be said that members of the family Cucurbitaceae stand a veritable position for use as active ingredients in food especially to provide remedy for protein and crude lipid deficiencies facing a large segments of populations of the underdeveloped and the developing nations where a large section of the populace depend on starchy foods. This is in addition to providing succor for animal feed fortification strategies to help ameliorate the problem of high cost of fish and poultry feeds.

\section{Notes on contributors}

Ibrahim Umar KARAYE is a Plant Biologist, a PhD. Student with a special interest in the Biochemical Properties in the Dicot families.

Muhammad HAYATU is a Reader in Plant Biology with interest is General Physiology.

Yahya MUSTAPHA is a Professor in Plant Biology with special interest in Plant Physiology.

Lawan Abdu SANI is a plant scientist with bias in general Plant Physiology and plant genetics.

\section{Acknowledgment}

The first author wishes to acknowledge the management of Usmanu Danfodiyo University, Sokoto and the Tertiary Education Trust Fund (TETFUND) Nigeria for study fellowship and sponsorship.

Authors declare that there is no existence of competing interest.

\section{References}

ABDELATIEF S. H. E. 2011. Chemical and biological properties of local Cowpea seed protein grown in Gizan Region, Saudi Arabia. International Journal of Agriculture: Research and Review. 1(2): 68-75.

ABASCAL K. \& YARMELL E. 2005. Using Bitter melon to treat Diabetes. Alternative and Complementary Therapy. 11(4): 179-184. https://doi.org/10.1089/act.2005.11.179 
ABIODUN O. A. \& ADELEKE R. O. 2010. Comparative studies on nutritional composition of four melon seed varieties. Pakistan Journal of Nutrition. 9(9): 905-908. https://doi.org/10.3923/pjn.2010.905.908

ACHU M. B., FOKOU E., TCHIEGANS C., FOTSO M. \& TCHOUANGUEP F. M. 2005. Nutritive value of some Cucurbitaceae oilseeds from different regions in Cameroon. African Journal of Biotechnology. 4(11): 13291334.

ADEDAPO A., ADEWUYI T. \& SOFIDIYA M. 2013. Photochemistry, anti-inflammatory and analgesic activities of the aqueous leaf extract of Lagenaria breviflora (Cucurbitaceae) in laboratory animals. Revista de Biologia Tropical. 1(1): 281-290. https://doi.org/10.15517/RBT.V61I1.11127

ADEYEYE E. L. 2002. Determination of chemical composition of the nutritionally valuable parts of male and female common west African fresh water crab Sudanaustes africanus africanus. International Journal of Food Science and Nutrition. 53(3): 887-892. https://doi.org/10.1080/09637480220132805

ATIF A., NAVEED A., BARKAT A. K., MUHAMMAD S. K., AKHTAR R., SHAHIQ U., NAYAB K., KHALID W., TARIQ M. \& LIAQAT A. 2012. Acacia nilotica; a plant of multipurpose medicinal uses. Journal of Medicinal Research. 6(9): 1492-1496.

AOAC. 2008. Official Methods of Analysis, $18^{\text {th }}$ edition. Washington, DC: Association of Analytical Chemists, USA. BISOGNIN D. A. 2002. Origin and Evolution of Cultivated Cucurbits. Ciêcia Rural. 32: 715-723.

GBOGOURI G. A., BROU K., LINDER M., TEHRANY E. A., GNARKI D. \& BI I. A. Z. 2011. Comparative study of Physicochemical and Thermal properties of the seed oils of three Cucurbits species. International Journal of Biological and Chemical Sciences. 5(3): 1165-1177. https://doi.org/10.4314/ijbcs.v5i3.72246.

DAVIES S. \& STEWART A. 1990. Nutritional Medicine. Avon Books, New York.

DUKE J. A. 1992. Handbook of Biologically active Phytochemical and their activities. Boca Raton, FL, CRC Press.

EL-ADAWY T. A. \& TAHA K. M. 2001. Characteristics and composition of watermelon, pumpkins and paprika seed oils and flours. Journal of Agricultural and Food Chemistry. 49(3): 1253-1239. https://doi.org/10.1021/jf001117

ELINGE C. M., MUHAMMAD A., ATIKU F. A., IDOTO A. U., PENI I. J., SANNI O. M. \& MBONGO A. N. 2012. Proximate, mineral and anti-nutrient Composition of Pumpkin (Cucurbita pepo L.) seeds extract. International Journal of Plant Research. 2(5): 146-150. https://doi.org/10.5923/j.plant.20120205.02

ESQUINAS-ALCAZAR J. T. \& GULICK P. J. 1983. Genetic Resources of Cucurbitaceae. International Board for Plant Genetic Resources, Rome, 101.

FAO. 1973. Energy and Protein Requirements. Food and Agricultural Organization of the United Nations, Rome.120122.

FELIX J. P. \& MELLO D. 2000. Farm Animal Metabolism and Nutrition. United Kingdom: CABI.

GUO S., LIU J., ZHENG Y., HUANG M., ZHANG H., GONG G., HE H., REN Y., ZHONG S., FEI Z. \& XU Y. 2011. Characterization of Transcriptome dynamics during watermelon fruit development: Sequencing, assembly, annotation and gene expression profiles. BMCGenomics. 12: 454. https://doi.org/10.1186/1471-2164-12-454.

GEMEDEH H. F. \& RATTA N. 2014. Antinutritional factors in plant foods: Potential health benefits and adverse effects. International Journal of Nutrition and Food Sciences. 3(4): 284-289. https://doi.org/10.11648/j.ijnfs.20140304.18

HAIM N. 2007. Seed production and germinability of Cucurbit Crops. Seed Science and Biotechnology. 1(1): 1-10.

HAMZA M. A. 1995. Factors affecting the extractability of defatted karkade (Hibiscus sabdariffa) seed flour. Journal of King Saud University. 7(2): 179-186.

HARBONE J. B. 1998. Phytochemical Methods a Guide to Modern Techniques of Plant Analysis. $3^{\text {rd }}$ Edition, Chapman and Hall, London, ISBN-139780412572708, PP 302-305.

HASSAN L. G., SOKOTO M. A., DANGOGGO S. M. \& LADAN M. J. 2006. Proximate, amino acid and minerals composition of silk cotton seeds (Ceiba pentandra). African Journal of Food Science. 9: 29-35.

HUTCHINSON J. D. 1954.The Families of Flowering Plants. Oxford University Press. 1: 242-244.

ILELABOYE N. O. A. \& PIKUDA O. A. 2009. Determination of minerals and anti-nutritional factors of some lesserknown crop seeds. Pakistan Journal of Nutrition. 8(10): 1652-1656. https://doi.org/10.3923/pjn.2009.1652.1656

JACOB A., ETONG D. I. \& TIJJANI A. 2015.Proximate, mineral and anti-nutritional composition of Melon (Citrullus lanatus) seeds. British Journal of Research. 2(5): 142-151.

JEFFREY C. 1978. Cucurbitaceae. Flora Zimbesiaca. 4: 419-429.

KARAYE I. U., ALIERO A. A., MUHAMMAD S. \& BILBIS L. S. 2013. Evaluation of nutrient and antinutrient contents of selected Nigerian cucurbits seeds. Research Journal of Pharmaceutical, Biological and Chemical Sciences. 4(1): 137-142.

KARAYE I. U., LADAN M. U., ADILI I. S., SHEHU A., LAWAL H. M. \& SAHABI M. H. 2020. Photochemistry and Proximate composition of fruit pulp and seeds of Desert date, Balanites aegyptiaca Del. International Journal of Science for Global Sustainability. 6(2): 109-117. 


\section{NUTRITIONAL AND ANTI-NUTRITIONAL PROPERTIES OF THE SEEDS OF SIX SELECTED ...}

KORTSE P. A. \& OLADIRAN A. J. 2013. The effects of leaf color at fruit harvest and fruit after-ripening duration on (Cucumeropsis mannii Naudin.) seed quality. Journal of Biology, Agriculture and Healthcare. 3(2): 190-201.

LIU J., GUO S., HE H., ZHANG H., GONG G., REN Y. \& XU Y. 2013. Dynamic characteristics of sugar accumulation and related enzyme activities in sweet and non-sweet watermelon fruits. Acta Physiologiae Plantarum. 35(1): 3213-3222. https://doi.org/10.1007/s11738-013-1356-0

LOEWUS F. A. 2002. Biosynthesis of Phytate in Food grains and Seeds. In: REDDY N. R. \& SATHE S. K. (eds.). Food phytates. CRC Press, Boca Raton, Florida: 53-61.

LOUKOU A. L., GNAKRI D., DJE Y., IPPRE A. V., MALICE M., BAUDOIN J. P. \& BI I. A.2007. Macronutrient composition of three cucurbits species cultivated for seed consumption in Cote d'Ivoire. African Journal of Biotechnology. 6(5):29-533.

MUZQUIZ M., BURBANO C., CUADRADO C. \& MARTIN M. 2000. Analytical methods for determination of compounds with no nutritive value. In: Handbook on Common Bean Related Laboratory Methods, Galicia, Spain: 11-26.

MUHAMMAD A. A. 2004. Chemical Composition and oil Characteristics of pumpkin seed kernel. Research Bulletin. By Food and Agricultural Research Centre, King Saud, University, Kingdom of Saudi Arabia. 129: 5-18.

MURRAY C. J. \& LOPEZ A. D. 1997. Global mortality, disability, and the contribution of risk factors: Global burden of disease study. Lancet. 349(9): 1436-1442. https://doi.org/10.1016/S0140-6736(96)07495-8

NEWEL C. A., ANDERSON L. A. \& PHILLIPSON J. D. 1996. Herbal Medicine-a Guide for Health care Professionals, the Pharmaceutical Press, London: 296.

NG T. J. 1993. New Opportunity in Cucurbitaceae. spp: 538-546. In: New Crops, Wiley, New York.

OBI A. I., AKPA T. C. \& ABUBAKAR S. E. 2004. Elemental analysis of some major Nigerian soup ingredients using X-ray fluorescence (XRF) and Kjeldahl Methods. Nigerian Journal of Scientific Research. 4(2): 13-66.

OBUTE G. C. NDUWU B.C. \& CHUKWO O. F. 2007. Targeted mutagenesis in Vigna unguiculata (L.) Walp. and Cucumeropsis mannii (Naud) in Nigeria. African Journal of Biotechnology. 6(21): 2467-2472.

ONIBON V. O., ABULUDE F. O. \& LAWAL L. O. 2007. Nutritional and Anti-nutritional composition of some Nigerian fruits. Journal of Food Technology. 5(2): 120-122.

PITRAT M., CHAUVET M. \& FOURY C. 1999. Diversity, history and production of cultivated cucurbits. ActaHorticulturae. 492: 21-28. https://doi.org/10.17660/ActaHortic.1999.492.1

PIZZORNO J. E. \& MURRAY M. T. 1985. A Textbook of Natural Medicine, John Beasty College Publications, Scuttle, Washington.

REDDEN R. J., CHEN W. \& SHARMA B. 2005. Chickpea Breeding and Management. United Kingdom: CABI.

ROBINSON R. W. \& DECKER-WALTERS D. S. 1997. What are Cucurbits. In: ROBINSON R. W. \& DECKERWALTERS D. S. 1997. Cucurbits. CAB International, Wallingford, Oxon, New York: 1-22.

SOKOTO M. A., HASSAN L. G., SALLEH M. A., DANGOGGO S. M. \& AHMAD H. G. 2013. Quality assessment and optimization of biodiesel from Lagenaria vulgaris (Calabash) seeds oil. International Journal of Pure and Applied Sciences and Technology. 15(1): 55-66.

SHANTHAKUMARI S., MOHAN V. \& BRITTO J. 2008. Nutritional evaluation and elimination of toxic principles in wild yam (Dioscorea spp.). Tropical and Subtropical Agroecosystems. 8: 319-325.

TREASE G. E. \& EVANS W. C. 1989. A Textbook of Pharmacolognosy, $12^{\text {th }}$ Edition, Bailliere Tindal Limited: 388400 .

UGWU F. M. \& ORANYE N. A. 2006. Effects of some processing methods on the toxic components of African breadfruit (Treculia africana). African Journal of Biotechnology. 5: 2329-2333.

VOSE J. R. 1980. Production and functionality of starches and protein isolates from legume seeds (field peas and horse beans). Cereal Chemistry. 57(6): 406-410.

WARRIER P. K., NUMBIAR V. P. K. \& RAMANKUTTY C. 1995. Indian Medicinal Plants. Orient Longman, Hyderabad: 292-298.

WERBACH M. 1991. Nutritional Influences on Mental illness-a source book of clinical research. Third Line Press Inc., Tarzana CA.: 360 pp..

YUSUF A. A., MOFIO B. M. \& AHMED A. B. 2007. Proximate and mineral composition of Tamarindus indica Linn. Science World Journal. 2(1): 1-4. https://doi.org/10.4314/swj.v2i1.51699

\section{How to cite this article:}

KARAYE I. U., HAYATU M., MUSTAPHA Y. \& SANI L. A. 2021. Nutritional and anti-nutritional properties of the seeds of six selected nigerian cucurbit germplasm. J. Plant Develop. 28: 139-150. https://doi.org/10.47743/jpd.2021.28.1.878 